\section{E. Skovlund svarer:}

Min erfaring er at kun et fåtall av manuskriptene som sendes til Tidsskriftet for publisering omhandler prospektive intervensjonsstudier. Mine «professorale skulderklapp» er rettet mot den store gruppen av forfattere som rapporterer fra en klinisk hverdag der forskningen oftest er av eksplorerende natur og mange prosjekter er basert på innhenting av journaldata. I et flertall av manuskriptene beskrives «tingenes tilstand», og forhåndsspesifiserte hypoteser synes ofte å mangle. Mitt poeng er at også denne typen forskning trenger en god plan.

Det er en selvfølge at kliniske utprøvninger og andre intervensjonsstudier er beskrevet i en detaljert forskningsprotokoll og følger regelverket.

\section{Eva Skovlund}

eva.skovlund@farmasi.uio.no

Eva Skovlund (f. 1959) er fungerende divisjonsdirektør, Divisjon for epidemiologi, Nasjonalt folkehelseinstitutt og professor II ved Universitetet i Oslo.

Ingen oppgitte interessekonflikter.

\section{Riktig definisjon av p-verdi?}

I et leserinnlegg i Tidsskriftet nr. 5/2013 kommenterer Carl Haakon Samuelsen (1) Eva Skovlunds definisjon av en p-verdi i en leder i Tidsskriftet nr. 1/2013 (2). Både Samuelsens og Skovlunds definisjon er nettopp publisert som to sider av samme sak i «Verktyg för klinisk forskning» i Läkartidningen. Om Skovlunds definisjon i praksis er riktig, er den etter mitt skjønn mye lettere å forstå. Det har en verdi i seg selv.

«P-värdet anger sannolikheten för att observera (om studien upprepades under samma förhållanden) ett samband minst så starkt som det som observerats, under förutsättning att det inte finns något samband (nollhypotesen). I praktiken anger alltså P-värdet sannolikheten för att det samband man observerat, eller ett ännu starkare samband, uppkommit av slumpen» (3).

\section{Erik Waage Nielsen}

erik.waage.nielsen@uit.no

Erik Waage Nielsen (f. 1956) er overlege ved Akuttmedisinsk avdeling, Nordlandssykehuset, Bodø og professor ved Universitetet i Troms $\varnothing$. Ingen oppgitte interessekonflikter.

\footnotetext{
Litteratur

. Samuelsen CH. Riktig definisjon av p-verdi? Tidsskr Nor Legeforen 2013; 133: 500

2. Skovlund E. Spør først, regn siden. Tidsskr Nor Legeforen 2013; 133: 10 .

3. Pettersson A, Gordon M, Edgren $G$ et al. Läkartidningen - Biostatistik har en central roll i epidemiologi. Lakartidningen 2013; 110: 470-4.
}

Dette er en redigert versjon av et innlegg publisert som rask respons på nett 18.3. 2013 http://tidsskriftet.no/article/2978933/

\section{Viktige fakta!}

Terje L. Berstad målbærer i Tidsskriftet nr. 5/2013 en av vår tids aller viktigste problemstillinger (1). Som brystkreftpasient gjennom halvannet år har jeg sett resultatet av at Norge bruker mindre på helse enn vi hittil har kommunisert og antatt. Om og om igjen har jeg sett hvordan leger, pleiere og andre lider under at de ikke får gjort en best mulig jobb fordi det periodevis skorter på alt fra grunnleggende materiale som brukbare kanyler, til alvorligere mangler som sengeplasser.

Helse-Norge har et erkjent organiseringsproblem. Men at finansieringen kun er på nivå med snittet i OECD, må frem i offentlighetens lys. Helseminister Jonas Gahr Støre påsto da han mottok nøkkelen til Helsedepartementet, at det «ikke er noen krise i HelseNorge». Jeg håper han i mellomtiden har skaffet seg bedre innsikt enn som så.

I et valgår der $41 \%$ av velgerne sier at helsepolitikken avgjør hva de skal stemme, er dette en uunngåelig debatt. Men da må folk flest opplyses om fakta.

\section{Lise Askvik \\ lise.askvik@P4.no}

Lise Askvik (f. 1969) er cand.mag., programleder i Radio P4, forkjemper for brystrekonstruksjon og forfatter av boken Kreft ga meg kraft. Oppgitte interessekonflikter: Forfatter kjenner Terje L. Berstad.

\section{Litteratur}

1. Berstad TL. Helseutgiftene i Norge er ikke spesielt høye. Tidsskr Nor Legeforen 2013; 133: 503

Dette er en redigert versjon av et innlegg publisert som rask respons på nett 11.2.2013 http://tidsskriftet.no/article/2979106/

\section{Misvisende gjengivelse}

Terje L. Berstad viser i sin kommentarartikkel i Tidsskriftet nr. 5/2013 (1) til et notat fra Stortingets utredningsseksjon (2).

Berstad hevder at Hans Olav Melberg i dette notatet konkluderer med at Norge bruker mye på helse. Vi ønsker å gjøre oppmerksom på at dette er en direkte misvisende gjengivelse av innhold og konklusjoner i Melbergs notat. I notatet gjennomgår Melberg derimot ulike mål på helseutgifter. Han viser også en del fordeler og ulemper ved bruk av kjøpekraftjusterte beløp i slike sammenhenger, inkludert Eurostats helsespesifikke prisindeks. Han konkluderer bl.a. med følgende: «Dersom vi likevel skal gi ett tall for å få et kortfattet svar på om vi bruker lite eller mye sammenlignet med andre, ville det vært best å bruke en helsespesifikk prisindeks. Da kommer vi nærmest noe av det vi er interessert i: Et mål på mengden helsetjenester som tilbys befolkningen. Et viktig arbeid er derfor å forbedre den helsespesifikke prisindeksen slik at den blir mer dekkende. Inntil da er det i de fleste sammenhenger best å holde seg til vanlig praksis og bruke kjøpekraftjusterte utgifter ved internasjonal sammenligning, men supplere med lønnsjusterte utgifter i en mer detaljert sammenligning» (2).

Dette er vesentlige nyanseringer av hovedinnholdet i Perspektiv 03/12 som Berstad bruker som utgangspunkt for sin artikkel.

\section{Toril F. Bergsjø}

toril.bergsjo@stortinget.no

Toril. F. Bergsjø (f. 1960) er cand.polit., Seniorrådgiver i Stortingets utredningsseksjon

Oppgitte interessekonflikter: Forfatter arbeider i seksjonen som har bestilt Perspektiv 03/12 som brukes som referanse i Berstads artikkel. 